Infusionstherapie 1973-74;1:501

\title{
Inhalt (Contents), Vol. 1, No. 7, 1973-74
}

Impressum (Imprint) 503

Ankündigung des redaktionellen Programms (Editorial Program) 506

Falser, N., Innsbruck

Serologische Untersuchungen an Blutspendern: II. Erweiterte immunologische Untersuchungen des Spenderblutes bei

Konservenempfängern mit gesteigertem Risiko (Serological Examinations in Blood Donors: II.

Enlarged Immunologic

Examinations of the Donor Blood in Blood Recipients with Raised Risk) 509

Buchbesprechungen (Book Reviews) 514

Symposion »Parenterale Ernährung « (Symposium “Parenteral Nutrition”)

Vorwort (Preface) 515

Hartmann, G., Chur

Fette in der parenteralen Ernährung (Fats in Parenteral Nutrition) 516

Eckart, J., Augsburg

Zur Verwertung von Fettemulsionen in der parenteralen Ernährung des Menschen (On the

Utilisation of Fat Emulsions in

Parenteral Nutrition of Man) 521

Zumtobel, V., Miinchen

Indikationen für eine parenterale Fettgabe in der Chirurgie (Indications for Parenteral Fat

Administration in Surgery) . . 531

Wolfram, G., Doenícke, A. und Zöllner, N., München

Die essentiellen Fettsäuren in den Cholesterinestern des Serums vor und in den Tagen nach einer Magenoperation (Essen

tial Fatty Acids of Serum Cholesterol Esters before and after Surgery of the Stomach) 537

Diskussion (Discussion) 541

Matzkies, F. und Berg, G., Erlangen

Das Verhalten von Lipiden während parenteraler Zufuhr von Kohlenhydraten (Reaction of

Lipids to Parenteral Adminis

tration of Carbohydrates) 545

Kaiser, W., Stocker, K. und Heuckenkamp, P.-U., München

Untersuchungen zum Mechanismus des Serumharnsäureanstiegs während kontinuierlicher

Xylitinfusionen (Studies on

Mechanism of Elevations in Serum Uric Acid Levels during Continuous Xylit Infusions) 548

Dietze, G., Wicklmayr, M., Hepp, K. D., Grunst, J., Stiegler, G. und Mehnert, H.

Der Stoffwechsel des Splanchnikusgebiets unter dem Einfluß von Fruktose (Metabolism of the Splanchnic Region under the

Influence of Fructose)

552

Bode, J. Ch., Marburg 
Unerwünschte Stoffwechselwirkungen bei Gabe höherer Dosen von Fruktose und Sorbit (Undesirable Metabolic Effects

Following Administration of Higher Doses of Fructose and Sorbitol) 558

Heuckenkamp, P.-U. und Zöllner, N., München

Glukose in der parenteralen Ernährung (Glucose in Parenteral Nutrition) 565

Haslbeck, M., München

Zur parenteralen Verabreichung von Zuckeraustauschstoffen mit besonderer Berücksichtigung des Diabetes mellitus (Par

enteral Administration of Sugar Substitutes with Special Reference to Diabetes mellitus) 569

Diskussion (Discussion) $\quad .578$

Buchbesprechungen (Book Reviews) 580

Zum Titel

Die acht auf der Titelseite aufgeführten Themengruppen stellen das redaktionelle Programm des ersten Bandes dieser Zeitschrift dar. Bei jenen Themengruppen, zu denen im Heft Arbeiten erscheinen, ist der vorangesetzte Kreis ausgefüllt.

(C) Copyright 1974 by S. Karger Verlag GmbH, Verlag für Medizin und Naturwissenschaften, D8034 Germering, Postfach 2 